\title{
EVALUATION OF THE MYCELIAL NETWORK FORMED BY ARBUSCULAR MYCORRHIZAL HYPHAE IN THE RHIZOSPHERE OF PAPAYA AND OTHER PLANTS UNDER INTERCROPPING SYSTEM
}

\author{
André Freire Cruz $^{1 *}$; Takaaki Ishii ${ }^{1}$; Isao Matsumoto²; Kazuomi Kadoya² \\ ${ }^{1}$ Faculty of Agriculture, Kyoto Prefectural University, Kyoto, Japan; ${ }^{2}$ Faculty of Agriculture, Ehime University, \\ Matsuyama, Ehime, Japan
}

Submitted: January 30, 2002; Returned to authors for corrections: July 17, 2002; Approved: January 24, 2003

\begin{abstract}
An experiment was carried out under greenhouse conditions to observe the distribution of arbuscular mycorrhizal (AM) hyphae in the rhizosphere of papaya and other plants under intercropping system. Special acrylic root boxes with three compartments, separated by nylon mesh screens, were constructed. One outer compartment contained seedlings of papaya (Carica papaya L.) and other contained seedlings of bahiagrass (Paspalum notatum Flügge) or millet (Pennisetum glaucum L. R. Br.). The central compartment was inoculated with an AM fungus (Gigaspora margarita). In another experiment, the outer compartments were treated with $25 \% \mathrm{MeOH}$ eluates of bahiagrass (BRE) and millet (MRE) root extracts. A control box, containning only papaya seedlings was also prepared. Hyphal density, root infection levels and spore numbers were higher in the bahiagrass and millet compartments than in the papaya compartment. Similar results were found for the percentage of AM infection and the number of AM spores. In the compartments treated with BRE and MRE the density of AM hyphae was around 20\%, and a few spores were found in those compartments. Few AM hyphae and spores were observed in the control compartment.
\end{abstract}

Key words: hyphae, root extracts, papaya, arbuscular mycorrhizal fungi

\section{INTRODUCTION}

Papaya (Carica papaya $\mathrm{L}$ ) is a widely consumed fruit in tropical areas and known for its high nutritive value. The utilization of arbuscular mycorrhizal (AM) fungi in economically important tropical crops, such as papaya, has been suggested $(1,14)$, also the papaya growth is significantly improved by the presence of Glomus clarum (17). Native fungi in general, even though not very efficient, have shown a high capacity for the colonization of papaya roots (13).

Bahiagrass and millet are grasses largely used as pasture in many regions of Brazil $(6,18)$. Millet is used as a rotational crop (2) in the maize and soybean areas, and sometimes as pasture in dry regions because of its tolerance to drought. The sod culture system, a grass intercropped with a fruit tree, with bahiagrass in satsuma mandarin orchards (Citrus unshiu Marc.) has been suggested to promote the propagation of symbiotic microorganisms, such as AM fungi (11). According to Oliveira (personal communication), the presence of some weeds has been shown to decrease the incidence of Fusarium solani $\mathrm{f}$. sp. in black pepper (Piper nigrum L.) roots. In an experiment in vitro (unpublished data), the 50 and $100 \% \mathrm{MeOH}$ eluates of bahiagrass and millet root extracts depressed the growth of Fusarium oxisporum. Therefore, the utilization of sod culture system also may be extended to the tropical areas where some soil diseases are problematic.

The formation of a network system by mycorrhizal hyphae in the rhizosphere between trifoliate orange intercropped with bahiagrass and millet has been shown $(3,4)$. In tropical areas, all cover crops intercropped with rubber trees were colonized by AMF (16). Thus, it is possible to hypothesize that the bahiagrass and millet can be used as cover crops in tropical areas to promote the AM propagation, because of their high photosynthetic activity in that areas.

\footnotetext{
* Corresponding author. Lab of Pomology, Fac. of Agriculture, Kyoto Prefectural University. 1-S Shimogamohangi-cho, Sakyo-ku, Kyoto 606-8522, Japan.
} 
The $25 \% \mathrm{MeOH}$ eluates of bahiagrass root extracts (BRE) in axenic culture have stimulated the growth of Gigaspora ramisporophora (10). Also, the BRE and $25 \% \mathrm{MeOH}$ eluates millet root extracts (MRE) could contribute to AM formation in trifoliate orange in vivo (4). The spore germination and growth of hyphae may be stimulated by root exudates $(3,5)$, such as flavonoids (12), but the utilization of these extracts, which contain AM stimulatory substances, has not yet been evaluated in tropical cultures.

When the hyphae are distributed in the soil between two plants or more, they are able to interconnect the plants. Therefore in this study we observed in vivo the mycelial network system formed by AM fungi in the presence of papaya roots seedlings and some grasses such as bahiagrass and millet. These results would give a large contribution to understand the network system formed by AM hyphae in the sod culture system. Moreover, the evaluation of the effects of root extracts (BRE and MRE) on the growth of AM hyphae in soils would greatly contribute to the proliferation of AM spores.

\section{MATERIALS AND METHODS}

This experiment was done in a green house condition without temperature control system. Acrylic root boxes were constructed and each root box (3-cm wide, $45-\mathrm{cm}$ long and $15-\mathrm{cm}$ deep) was divided into three compartments (Fig. 1). The central compartment (3-cm wide, $5-\mathrm{cm}$ long and $15-\mathrm{cm}$ deep) was separated from the two outer zones by a barrier made of nylon screen $(37 \mu \mathrm{m}$ mesh) that could allow only passage of AM hyphae but not of plant roots (Fig. 1). The pots were covered with aluminum foil to block the light and prevent algae growth.

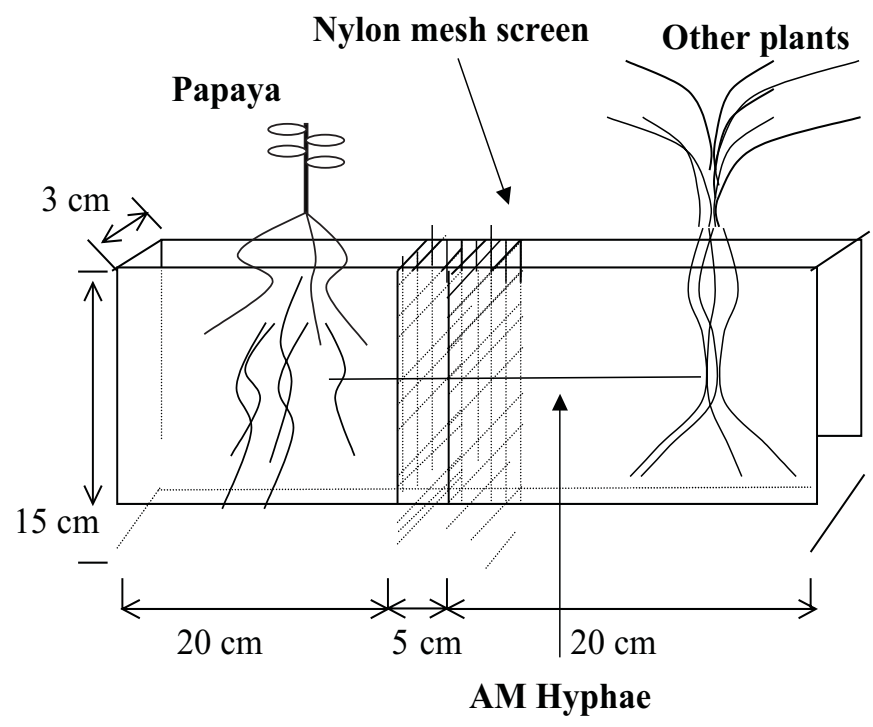

Figure 1. Design of the root box.
Each box was filled with a commercial clay substrate. The sterilization was done by adding chloropiclin into the substrate, and covering with a plastic film. One week later the plastic was removed and the substrate was kept on air during one week to release the chloropiclin.

Papaya seeds were initially sown in trays containing vermiculite, and then transplanted to one of the outer compartments in all boxes. Bahiagrass and millet were separately transplanted into the other compartments. Other plots were prepared with papaya in one outer compartment and $25 \% \mathrm{MeOH}$ eluates of BRE or MRE into the other outer one. The procedures to obtain the root extracts followed a previous paper (12). The compartments were treated equivalent to $1 \mathrm{~g}$ of fresh weight of these compounds once a week until the harvest time. A plot with only papaya seedlings was also prepared as a control. The inoculation was done in the central compartment with around 100 spores of Gigaspora margarita.

Two months after transplanting, the aluminum cover was removed and the density of hyphae measured. This parameter was quantified by examining an area of $12.8 \times 9.3 \mathrm{~mm}$ in each compartment using a charge coupled device (CCD) camera (Keyence VH-7000). It was measured 10 samples from each compartment. On a computer screen this area was divided into 200 squares, and the density of hyphae was calculated by using the following equation: Density of hyphae $(\%)=($ Squares with hyphae / 200 squares) x 100. Soil samples were taken to evaluate the number of spores in $25 \mathrm{~g}$ soil according to the procedures written by Ishii et al. (11). Root samples were taken, washed and stained by the technique of Phillips and Hayman (15). The percentage of AM infection in the roots was determined by the methods already described in a previous paper (9).

\section{RESULTS}

As shown in Fig. 2, in the plots of PR $x$ BR and PR $x$ MR the density of hyphae in the compartment of BR and MR was higher than that in the compartment of PR. In the control plots (PR x NP), the hyphae in the compartment of PR were observed, but a few hyphae was observed in the compartment of NP. Furthermore, in the compartments with BRE and MRE in the plots of PR $x$ BRE and PR $x$ MRE, the density of hyphae was around $20 \%$.

The percentage of AM infection was lower in the PR than in BR and MR in the plots of PR $x$ BR and PR $x$ MR (Fig. 3). Fig. 4 showed that in the plots of PR $x$ BRE and PR $x$ MRE the percentage of infection in the PR was higher than that in the plot of PR $x$ NP.

The number of spores was greater in $\mathrm{BR}$ and MR than in $\mathrm{PR}$ compartments in the plots of PR x BR and PR x MR (Fig. 5). Furthermore, when the BRE and MRE were applied to the compartment of NP (PR x BRE and PR x MRE), some spores in the compartments of BRE and MRE were observed. Few spores were, however, found in the NP compartment in the control plot (PR x NP). 


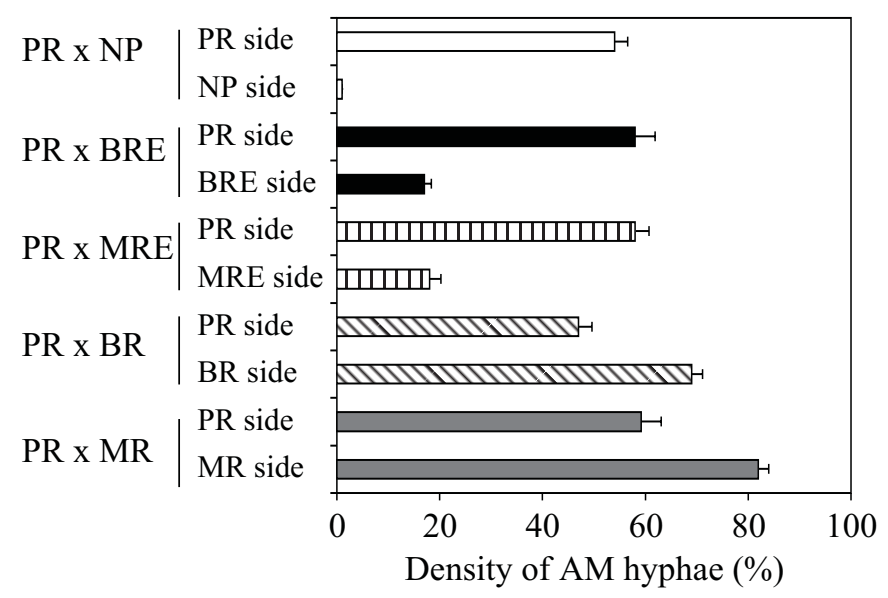

Figure 2. Density of AM hyphae in the compartments of papaya (PR), Bahiagrass (BR), millet (MR) and in the compartments treated with some root extracts in a root box system. BR - Bahiagrass roots; MR - Millet roots; NP - No plants; PR - Papaya roots; BRE - 25\% $\mathrm{MeOH}$ elutes of bahiagrass root extracts (Equivalent to $1 \mathrm{~g} \mathrm{FW}$ of bahiagrass roots); MRE - 25\% MeOH elutes of millet root extracts (Equivalent to $1 \mathrm{~g} \mathrm{FW}$ of millet roots). Horizontal bars indicate standard error (SE) $(n=4)$.

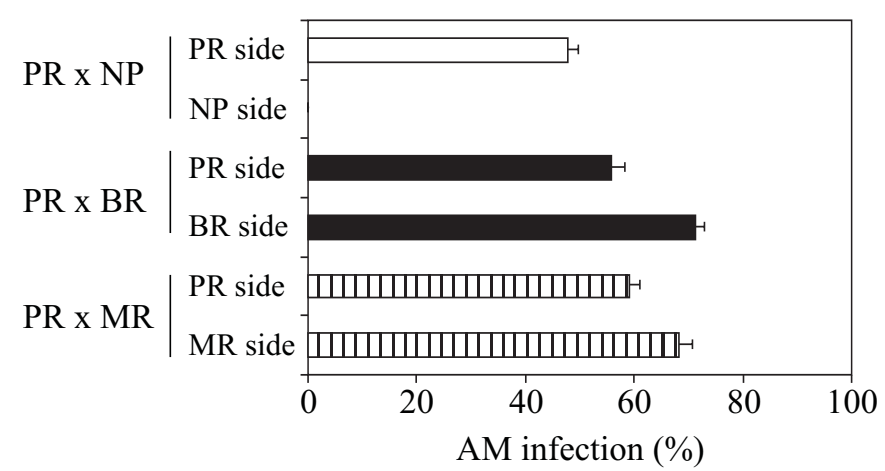

Figure 3. The percentage of AM infection in the root of papaya (PR), Bahiagrass (BR) and Millet (MR) in a root box system. BR - Bahiagrass roots; MR - Millet roots; NP - No plants; PR Papaya roots. Horizontal bars indicate SE $(n=4)$.

\section{DISCUSSION}

The root colonization and the formation of spores in the outer compartments confirmed the growth of AM hyphae from the central compartment to the outer ones. The CCD camera images showed the existence of new spores with similar surface characteristics as those of G. margarita, and no other contaminating spores were found in the soils of the outer

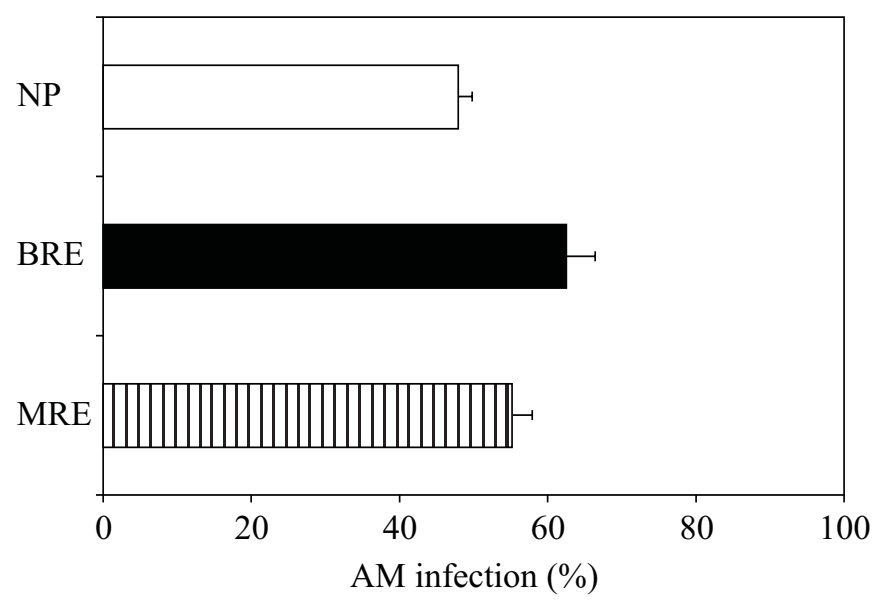

Figure 4. The percentage of AM infection in papaya roots where some root extracts were applied in a root box system. NP - No plants; BRE-25\% MeOH elutes of bahiagrass root extracts (Equivalent to $1 \mathrm{~g}$ FW of bahiagrass roots); $\mathrm{MRE}-25 \% \mathrm{MeOH}$ elutes of millet root extracts (Equivalent to $1 \mathrm{~g} \mathrm{FW}$ of millet roots). Horizontal bars indicate $\mathrm{SE}(\mathrm{n}=4)$.

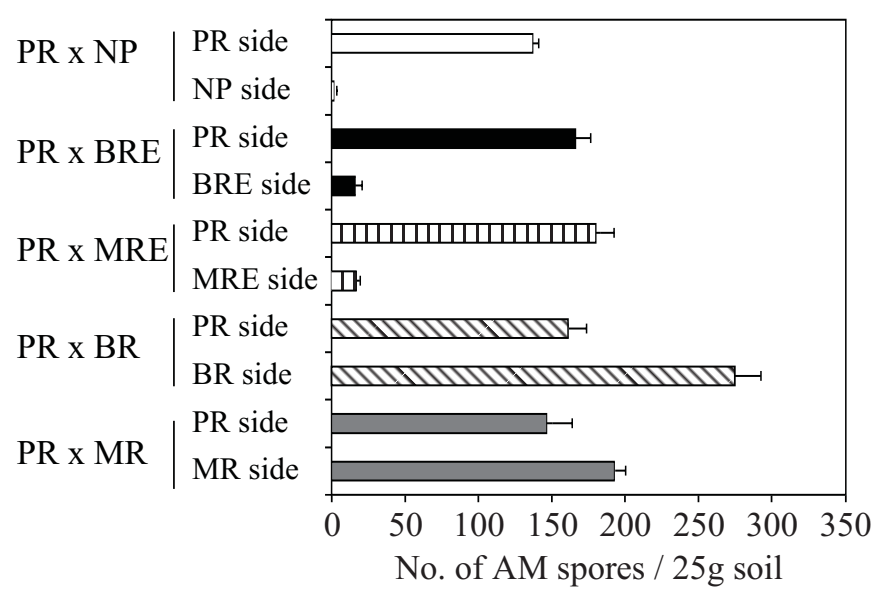

Figure 5. Number of AM spores in the compartments of papaya (PR), Bahiagrass (BR), millet (MR) and in the compartments treated with some root extracts in a root box system. BR Bahiagrass roots; MR - Millet roots; NP - No plants; PR Papaya roots; BRE - 25\% MeOH elutes of bahiagrass root extracts (Equivalent to $1 \mathrm{~g}$ FW of bahiagrass roots); MRE-25\% $\mathrm{MeOH}$ elutes of millet root extracts (Equivalent to $1 \mathrm{~g} \mathrm{FW}$ of millet roots). Horizontal bars indicate $\mathrm{SE}(\mathrm{n}=4)$.

compartments (data not shown). Also, the clay substrate bought in a market was already sterilized, and the sterilization was done by a second time with chloropiclin to be sure that the native species would be eliminated. Thus, the colonization in the plants 
of the outer compartments was due to the germination of the spores in the center compartment and the growth of mycelia to the outer ones. The connection formed between two or more different plants by AM hyphae promotes a network in the soilplant system. Under environmental conditions this network may benefit the plants, especially when a nutrient exchange between plants occur to maintain the nutrient in the plant system and decrease the loss to the soil $(3,11)$.

The data of hyphal density, AM infection and spore number demonstrated that the signals sent by the root exudates might promote the AM infection. These results indicate that bahiagrass and millet are effective to contribute for the formation and maintenance of AM fungi in the soils cultivated with papaya. Similar results were found in an experiment in vitro, where root exudates from bahiagrass stimulated the growth of hyphae in vitro (3). Some weeds have been demonstrated to affect the intensity of AM formation in citrus roots $(7,8)$. The bahiagrass may be recommended as a sod culture in citrus orchards, since they become dormant during the winter and the effects of competition between the grass and the tree are less severe (11). However, in the areas of papaya orchards, whose winter is not so cold, the grass can grow vigorously all the time, and consequently may depress the growth of the papaya tree. Therefore, it is necessary to evaluate what is the best stage of papaya growth to introduce these grasses, so that the sod culture can benefits the main culture without depressing the plant growth.

A low number of spores were found in the outer compartments containing only BRE and MRE. However, it is not clear if the formation of the spores in those compartments could be attributable to the root exudates released from the papaya in the opposite outer compartment, or to the efficiency of the BRE and MRE. The root extracts of bahiagrass were functional in vitro $(10,12)$. Since the AM stimulatory substances in BRE are soluble in water, they can easily diffuse in the soil and may work on the proliferation of AM fungi even in the absence of the host plants.

Three stimulatory substances were isolated in bahiagrass roots by flash chromatography and one of them was identified as eupalitin (11). This substance demonstrated to stimulate in vitro hyphal growth of Gigaspora ramisporophora (10).

In this work we observed an in vivo the distribution of AM hyphae in the soils of papaya and grasses grown side by side under an intercropping system. If these hyphae could interconnect two neighbouring plants to establish a network system, it is possible to speculate that a network system on these plants might be established under similar environmental conditions in sod culture $(3,4,11)$. In particular, the root extracts from bahiagrass and millet would significantly function as stimulatory substances to the formation of AM fungi in soils. The sod culture system with bahiagrass has been shown efficiency in citrus orchards $(7,8,11)$, and functioned well in this experiment with papaya. They can provide the propagation of AM fungi, and contribute to improve the efficiency of native AM species to benefit the plant growth. Further studies are now required to evaluate under field conditions the utilization of sod culture in papaya orchards, and to evaluate the efficiency of these extracts under field conditions because of the influence of external factors.

\section{ACKNOWLEDGMENTS}

This work was supported in part by a grant-in-aid for Scientific Research (No. 11460014) from the Ministry of Education, Science and Culture, Japan.

\section{RESUMO}

\section{Avaliação da rede micelial formada por hifas de fungos micorrízico-arbusculares na rizosfera de mudas de mamoeiro e outras plantas sob sistema de consórcio}

Um experimento foi conduzido em casa-de-vegetação para observar a distribuição de hifas de fungos micorrízicos arbusculares (FMA), na rizosfera do mamoeiro intercalado com outras plantas. Para isto foram construídos vasos de acrílico divididos em três compartimentos. Mudas de mamoeiro (Carica papaya $\mathrm{L}$.) foram transplantadas para um dos compartimentos laterais em todos os vasos, enquanto que mudas de grama batatais (Paspalum notatum Flügge) e milheto (Pennisetum glaucum L. R. Br.) foram separadamente transplantadas para o outro compartimento situado na outra extremidade. Um outro tratamento foi constituído de mudas de mamoeiro em um compartimento e $25 \%$ de extrato metanólico de raízes de grama batatais (BRE) ou de milheto (MRE), fracionados em cromatógrafo de coluna. Um vaso com apenas mudas de mamoeiro foi preparado como testemunha. O compartimento central foi inoculado com o fungo Gigaspora margarita. A densidade de hifas, a percentagem de infecção micorrízica e o número de esporos nos compartimentos com grama batatais e milheto foram maiores do que naqueles com mamoeiro. Nos compartimentos com BRE e MRE e algumas hifas e esporos foram observados nestes compartimentos. Naqueles sem planta, foram observadas poucas hifas ou esporos.

Palavras-chave: hifas, extrato metanólico, mamoeiro, fungos micorrízico-arbusculares.

\section{REFERENCES}

1. Casagrande R.; Machado, J.O.; Ruggiero, C.; Banzatto, D. Eficiência de inóculos de fungos endomicorrízicos sobre o desenvolvimento inicial do mamoeiro (Carica papaya L.) cv Sunrise Solo. Proceedings of the VIIIth Brazilian Congress on Fruit Culture, Brasilia, vol. II, 1986, p. 365-370. 
2. Cobucci, T.; Prates, H.T.; Falcão, C.L.M.; Rezende, M.M.V. Effect of imazamox, fomesafen, and acifluorfen soil residue on rotational crops. Weed Sci. Soc. Am., 46 (2): 258-263, 1998.

3. Cruz, A.F.; Ishii, T.; Kadoya, K. Distribution of vesicular-arbuscular mycorrhizal hyphae in the rhizosphere of trifoliate orange and Bahia grass seedlings under an intercropping system. J. Japan. Soc. Hort. Sci., 69 (3): 237-242, 2000.

4. Cruz, A.F.; Ishii, T.; Matsumoto I.; Kadoya, K. Distribution of vesicular-arbuscular mycorrhizal hyphae in the rhizosphere between trifoliate orange seedlings and some plants. J. Japan. Soc. Hort. Sci., 69 (Suppl. 1), 2000, p. 92 (In Japanese).

5. Cruz, A.F.; Ishii, T.; Matsumoto I.; Kadoya, K. Effect of root exudates on growth of vesicular-arbuscular mycorrhizal hyphae in vitro. J. Japan. Soc. Hort. Sci., 69 (Suppl. 2), 2000, p. 127 (In Japanese).

6. Dematte, M.S.E.P.; Haag, H.P.; Perecin, D.; Vasques, L.H. Application of nitrogen, phosphorus, potassium, organic fertilizer and dolomitic lime as related to seed production of Paspalum notatum Flügge in a Dark. An Esc. Sup. Agric. Luiz de Queiroz. Piracicaba, Brazil, 44 (1): 571-616, 1987. (In Portuguese with English summary).

7. Ishii, T.; Tasumi, K.; Kadoya, K. Distribution and ecological aspects of vesicular arbuscular mycorrhizal fungi in citrus orchards. Mem. Coll. Agr., Ehime Univ., 34: 65-71, 1989.

8. Ishii, T.; Tasumi, K.; Kadoya, K. VA mycorrhizal development of citrus trees as affected by soil management. J. Japan. Soc. Hort. Sci., 58 (suppl. 1) 32-33, 1989. (In Japanese).

9. Ishii, T.; Kadoya, K. Effects of charcoal as a soil conditioner on citrus growth and vesicular-arbuscular mycorrhizal development. $J$. Japan. Soc. Hort. Sci., 63 (3): 529-535, 1994.

10. Ishii, T.; Matsumoto, I.; Shrestha, Y.H.; Murata, H; Kadoya, K. Axenic culture of vesicular-arbuscular mycorrhizal fungi and their infectivity to several plant roots. J. Japan. Soc. Hort. Sci., 64 (1): 190-191, 1995.

11. Ishii, T.; Shrestha, Y.H.; Kadoya, K. Effect of sod culture system of Bahia grass (Paspalum notatum Flügge.) on vesicular-arbuscular mycorrhizal formation of Satsuma Mandarin trees. Proc. Int. Soc. Citriculture, 822-824, 1996.

12. Ishii, T.; Narutaki, A.; Sawada, K.; Aikawa, J.; Matsumoto, I.; Kadoya, K. Growth stimulatory substances for vesicular-arbuscular mycorrhizal fungi in Bahia grass (Paspalum notatum Flügge.) roots. Plant and Soil, 196: 301-304, 1997.

13. Jaizme-Vega, M.C.; Azcón, R. Responses of some tropical and subtropical cultures to endomycorrhizal fungi. Mycorrhiza, 5: 213217, 1995.

14. Mohandas, S. Effect of VAM inoculation on plant growth, nutrient level and root phosphatase activity in papaya (Carica papaya cv. Coorg Honey Dew). Fert. Res., 31: 263-267, 1992.

15. Phillips, J.M.; Hayman, D.S. Improved procedures for clearing roots and staining parasitic and vesicular-arbuscular mycorrhizal fungi for rapid assessment of infection. Trans. Br. Mycol. Soc., 55: 158-161, 1970.

16. Schwob, I.; Ducher, M.; Coudret, A. Effect of climatic factors on native arbuscular mycorrhizae and Meloidogyne exigua in a Brazilian rubber tree (Hevea brasiliensis) plantation. Plant Path., 48: 19-25, 1999.

17. Silva, L.F.C.; Siqueira, J.O. Crescimento e teores de nutrientes de mudas de abacateiro, mangueira e mamoeiro sob influência de diferentes espécies de fungos micorrízicos vesículo-arbusculares. $R$. Bras. Ci. Solo, 15: 283-288, 1991.

18. Uemura, Y.; Filho, G.U.; Netto, D.A.M. Pearl millet as a cover crop for no till soybean production in Brazil. Int-sorghum-millets-newsl: Sorghum Improvement Council of North America, 38: 141-143, 1997. 